\title{
Involvement of Anopheles nili in Plasmodium falciparum transmission in North Benin
}

\author{
Razaki A. Ossè ${ }^{1,2 *}$, Filémon Tokponnonn 2,3 , Germain Gil Padonou ${ }^{2,4}$, Aboubakar Sidick ${ }^{2}$, Rock Aïkpon 2,5, \\ Arsène Fassinou ${ }^{2,4}$, Come Z. Koukpo ${ }^{2,4}$, Wilfrid Sèwadé2 ${ }^{2}$ Bruno Akinro ${ }^{2}$, Arthur Sovi ${ }^{2,6}$, Melchior Aïssi $^{7}$ \\ and Martin C. Akogbéto
}

\begin{abstract}
Background: Several studies carried out in Benin have shown the involvement of Anopheles gambiae sensu lato (s.l.), the Anopheles funestus group in malaria transmission, but none of them reported the contribution of the Anopheles nili group to the transmission of this disease. The current study investigated the question through an entomological cross-sectional survey performed in Northern Benin.
\end{abstract}

Methods: Mosquito samplings were performed in September and October 2017 in 4 villages located in two districts: Bambaba and Wodara (Kérou district) and, Péhunco 2 and Béké (Péhunco district). The collections were carried out indoors and outdoors using human landing catches (HLC) to assess the human biting rate (HBR) and pyrethrum spray catches (PSC) to evaluate the blood feeding rate and the blood meal origin using the ELISA test. All collected mosquitoes were morphologically identified and, the polymerase chain reaction (PCR) technique was used for molecular identification of sibling species of An. gambiae s.l., An. funestus group and An. nili group sporozoite index (SI) was also assessed by the ELISA test.

Results: Overall, An. gambiae s.l., An. funestus group and An. nili group were the three vectors found in the study area. A significantly higher human biting rate (HBR) was recorded in An. nili group (5 bites/human/night) compared to An. funestus group ( 0.656 bites/human/night) in the Kérou district ( $p<0.0001)$. Anopheles gambiae s.l. displayed the highest HBR (26.19 bites/human/night) in the same district. The entomological inoculation rate (EIR) was 1.875 infected bites/human/month in An. nili group against 13.05 infected bites/human/month in An. gambiae s.l. and 0.938 infected bites/human/month in An. funestus group in Kérou. In Péhunco, the EIR was 1.02 infected bites/human/month in An. gambiae s.l. PCR results showed that An. nili sensu stricto (s.s.) and An. funestus s.s. were the only species of the An. nili and An. funestus groups, respectively. The anthropophagic character of An. gambiae s.l. was also highlighted.

Conclusion: This study provides useful information on the contribution of An. nili group as secondary vector to malaria transmission in northern Benin. Broader studies must also be carried out in a larger study area to assess the involvement of other Anopheles species to malaria transmission. This will aid to better plan malaria vector control interventions.

Keywords: Malaria, EIR, Anopheles nili, Contribution, Benin

\footnotetext{
*Correspondence: ossraz@yahoo.fr

${ }^{2}$ Centre de Recherche Entomologique de Cotonou (CREC),

06 BP 2604 Cotonou, Benin

Full list of author information is available at the end of the article
} 


\section{Background}

A wide range of human and animal diseases are transmitted by mosquitoes and those diseases remain a major source of death worldwide [1]. Malaria remains one of the most serious vector-borne diseases, affecting half of the world's 7.4 billion people [2]. The proliferation of mosquitoes is promoted not only by ecological changes due to human activities (deforestation, public works, construction of dams, rice paddies, irrigation), but also by environmental parameters (rainfall, temperature and relative humidity), which also play a fundamental role in the level of transmission and the epidemiology of diseases [3, 4]. In intertropical Africa, malaria transmission is very heterogeneous due to eco-climatic variations [5]. Currently, five species of the parasite of the Plasmodium genus have been identified as responsible for malaria infection in humans [6]. Among them Plasmodium falciparum remains the most virulent species causing the deadly forms of malaria [7]. The Plasmodium species responsible for human malaria are mainly transmitted by primary vector species, such as Anopheles gambiae sensu lato (s.l.), Anopheles funestus group and Anopheles nili group $[8,9]$. The existence of those different species complexes in an area represents a great challenge for malaria control programmes. Anopheles nili group has a wide geographical distribution in most of tropical Africa [10] and its preferential habitats are fast-flowing, upright-flowing streams, large rivers or dense shade along streams [7]. It is a group that includes four species, including $A n$. nili sensu stricto (s.s.), Anopheles carnevalei, Anopheles somalicus and Anopheles ovengensis [8, 11].

In Benin, over the past two decades, the roles of $A n$. gambiae s.l. and An. funestus group in the transmission of $P$. falciparum in several regions of the country have been studied by several authors [12-19]. Few of these studies have shown the presence of $A n$. nili group in the different surveyed areas. Moreover, none of them has demonstrated its involvement in malaria transmission in Benin. It is in this context that a large population of An. nili group was collected during this cross-sectional survey conducted in the districts of Kérou and Péhunco located in the Atacora region. Thus, the possible involvement of this Anopheles species in the transmission of $P$. falciparum was investigated in the study area.

This study aims at providing information on vector species composition involved in malaria transmission in the areas of Kérou and Péhunco (northwestern Benin) where there is a lack of data.

\section{Methods}

\section{Study area}

This study was conducted from September to October 2017 in the districts of Kérou and Péhunco, both located in the north-western Benin (Fig. 1). The two districts have a Sudano-Guinean climate characterized by a rainy season, from mid-April to mid-October, and a dry season from mid-October to mid-April. They belong to an agroecological zone characterized by an average annual rainfall of $1000 \mathrm{~mm}$. The average temperature varies between 25 in August and $31^{\circ} \mathrm{C}$ in April.

The district of Kérou is irrigated by two large permanent rivers, the Mekrou and the Pendjari as well as of many tributaries from the Alibori river. Péhunco is drained by the river Mekrou and also by many rivers. The most important economic activity of these two districts is agriculture, especially with the cultivation of cotton, sorghum and cashew nuts [20].

\section{Mosquito sampling and processing on the field}

In each district, two villages were selected for mosquito collections, Wodara and Bambaba (respectively central and peripheral village of the Kérou district) and, Péhunco 2 and Béké (respectively central and peripheral village of the Péhunco district). Collections of mosquitoes were performed using both human landing catches (HLC) and pyrethrum spray catches (PSC).

HLCs were carried out in two houses per village. Four sessions of night collections were organized each month with one human sitting inside and another one outside of each house, bringing to a total of 16 human-nights/ village/month and a total of 32 human-nights/district/ month.

For PSCs, 10 bedrooms were surveyed in each district ( 5 in the central village and the remaining 5 in the peripheral village) to collect early in the mornings, all mosquitoes that have entered the houses the night before. Thus, aerosol bombs (Rambo ${ }^{\circledR}$ ) containing $0.25 \%$ transfluthrin and $0.20 \%$ permethrin were sprayed in the houses and white canvas were spread on the floor for the collection of fallen mosquitoes.

Mosquitoes caught by both methods were morphologically identified using a mosquito identification key [21] and, the ovaries of the Anopheles vectors were dissected to determine the parity rate [22]. Anopheles vectors collected by PSCs were classified according to the physiological state of their abdomens (unfed, fed, half gravid, gravid) to determine the blood feeding rate. The Anopheles vectors collected with the two sampling methods were then stored in tagged eppendorf tubes containing silica gel and cotton for subsequent laboratory analysis.

\section{Laboratory analysis}

539 head-thoraxes of Anopheles vectors collected indoor and outdoor through HLC were crushed and then analysed by the ELISA tests for the determination of the circumsporozoite protein (CSP) positivity of Plasmodium 


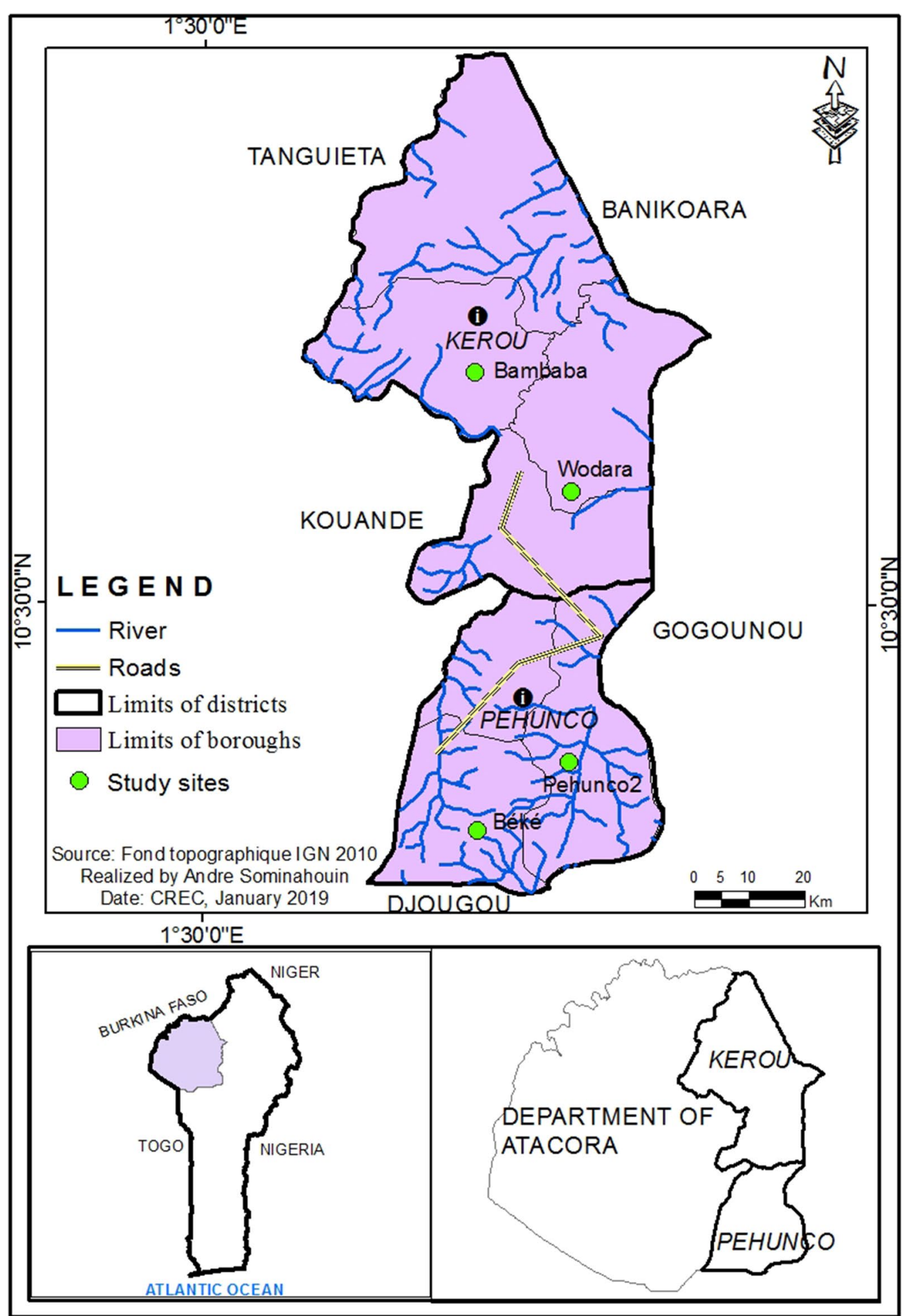

Fig. 1 Map of the study area 
falciparum using the protocol of Wirtz et al. [23]. This allows the determination of the sporozoite index (SI). The legs, wings, and abdomens of these mosquitoes were used for DNA extraction to perform molecular species identification.

The PCR technique based on the protocols of Santomalazza et al. [24], Koekemoer et al. [25] and Kengne et al. [26] was used to identify the sibling species of $A n$. gambiae complex, An. funestus group and An. nili group, respectively. In An. gambiae s.l., the presence of L1014F $k d r$ and G119S ace-1 mutations was determined following the methods of Martinez-Torres et al. [27] and Weill et al. [28], respectively. Moreover, the blood meal origin was sought in the blood fed Anopheles mosquitoes collected by PSC, using a direct enzyme immunoassay (ELISA) according to the method of Beier et al. [29] with human, cattle, sheep, chicken and pig antibodies.

\section{Data analysis}

The results were processed and analysed using the $R$ Core Team software (Version 3.5.1-2018) and Excel spreadsheets. The human biting rates $(\mathrm{HBR}=$ number of collected vectors/number of humans/number of nights), infection rates (Number of infected mosquitoes/total tested), entomological inoculation rates $\left(E I R_{\text {night }}=\mathrm{HBR} \times\right.$ infection rate; $\left.\mathrm{EIR}_{\text {month }}=\mathrm{EIR}_{\text {night }} \times 30\right)$ and parity rates (Number of parous mosquitoes/total tested) were calculated and compared between species of the same district. The Poisson test allowed us to compare the HBRs and EIRs between species in the district of Kérou. The comparison of parity rates, infectivity and allelic frequencies of L1014F $k d r$ and G119S ace-1 mutations by species and by site were made with the Chi square comparison test.

\section{Results}

\section{Mosquito species composition and molecular} identification of sibling species of Anopheles gambiae complex, Anopheles funestus group and Anopheles nili group

The mosquito fauna collected in both surveyed districts was very diverse (Table 1). A total of 1558 mosquitoes divided into 12 different species were collected with a predominance of Anopheles species (83.25\%: 1297/1558).

In Péhunco, out of the collected mosquitoes, $36.36 \%$ (128/352) were An. gambiae s.l. and 0.3\% (1/352) An. funestus group. In the Kérou district, 9 species were collected. Among those species, An. gambiae s.l. was the most abundant (69.48\%: 838/1206) followed by An. nili group (13.27\%: 160/1206), Anopheles brohieri (8.37\%: 101/1206), Anopheles ziemanni (3.90\%: 47/1206) and An. funestus group (1.74\%: 21/1206).
Table 1 Mosquito species composition in Péhunco and Kérou between September and October 2017

\begin{tabular}{|c|c|c|c|c|c|}
\hline \multirow[t]{2}{*}{ Species } & \multicolumn{2}{|c|}{ Péhunco } & \multicolumn{2}{|l|}{ Kérou } & \multirow[t]{2}{*}{ Total } \\
\hline & Indoor & Outdoor & Indoor & Outdoor & \\
\hline Anopheles gambiae s.l. & 74 & 54 & 430 & 408 & 966 \\
\hline $\begin{array}{l}\text { Anopheles funestus } \\
\text { group }\end{array}$ & 0 & 1 & 9 & 12 & 22 \\
\hline Anopheles nili group & 0 & 0 & 51 & 109 & 160 \\
\hline Anopheles pharoensis & 0 & 0 & 0 & 1 & 1 \\
\hline Anopheles ziemanni & 0 & 0 & 14 & 33 & 47 \\
\hline Anopheles brohieri & 0 & 0 & 19 & 82 & 101 \\
\hline $\begin{array}{l}\text { Anophelinae (sub } \\
\text { total 1) }\end{array}$ & 74 & 55 & 523 & 645 & 1297 \\
\hline Aedes aegypti & 0 & 0 & 1 & 0 & 1 \\
\hline Aedes vitatus & 0 & 0 & 0 & 2 & 2 \\
\hline Culex quinquefasciatus & 127 & 91 & 18 & 16 & 252 \\
\hline Culexnebulosus & 0 & 2 & 0 & 0 & 2 \\
\hline Culex tigripes & 1 & 0 & 0 & 0 & 1 \\
\hline Mansonia africana & 1 & 1 & 0 & 1 & 3 \\
\hline Culicinae (sub total 2) & 129 & 94 & 19 & 19 & 261 \\
\hline Grand total & 203 & 149 & 542 & 664 & 1558 \\
\hline
\end{tabular}

PCR results showed the presence of An. gambiae and An. coluzzii as sibling species of the An. gambiae complex in both Péhunco and Kérou. Anopheles gambiae was found in majority $(96.43 \%$ and $78.43 \%$ at Péhunco and Kérou, respectively). In addition, all mosquito specimens of the An. funestus group (Péhunco and Kérou) and the An. nili group (Kérou) were found to be An. funestus s.s. and An. nili s.s., respectively (Fig. 2).

\section{Biting behaviour, $\mathrm{HBR}$, SI and EIR}

In Kérou, the An. nili group was exophagic as the proportion of this species caught outdoors (68.13\%: 109/160) was significantly higher than that recorded indoors $(31.87 \%$ : $51 / 160)(\mathrm{p}<0.0001)$. In the same district the indoor (51.31\%: 430/838) and the outdoor (48.69\%: 408/838) biting behaviour of An. gambiae s.l. was similar $(\mathrm{p}=0.282)$, as was also observed for the An. funestus group [indoors proportion: $42.86 \%$ (9/21); outdoors proportion: $57.14 \%$ (12/21); $\mathrm{p}=0.35$ ]. However, in Pehunco, An. gambiae s.l. was endophagic [Indoors proportion: $57.81 \%$ (74/128); Outdoors proportion: 42.19\% (54/128); $\mathrm{p}=0.011$ ] (Table 1).

In the district of Kérou, the biting rate of An. gambiae s.l. (26 bites/human/night) was significantly higher than that of the An. nili group (5 bites/human/night) $(\mathrm{p}<0.0001)$. The biting rate of An. funestus group (0.656 bites/human/night) was significantly lower than that of An. gambiae s.l. and An. nili group ( $\mathrm{p}<0.0001)$. The trend was the same between An. funestus group and An. gambiae s.l. in Péhunco $(\mathrm{p}<0.0001)$ (Table 2). 

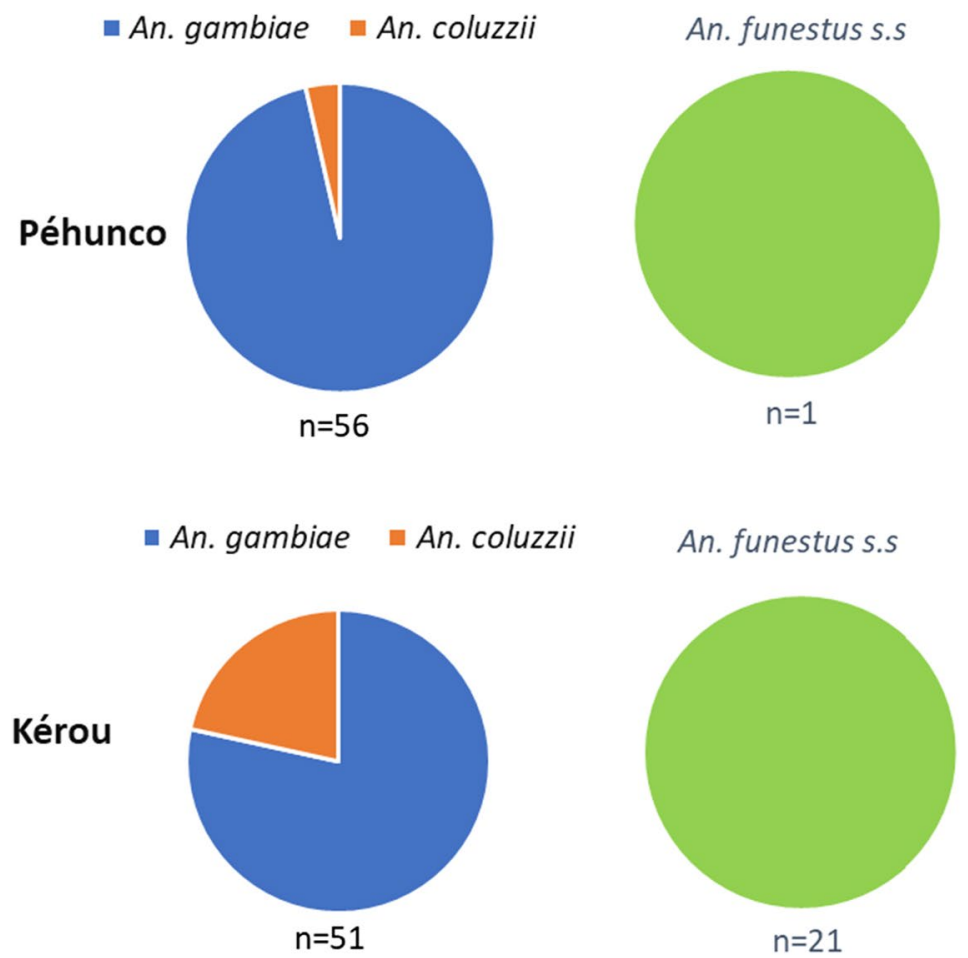

Fig. 2 Distribution of sibling species within the An. gambiae complex and the An. funestus and An. nili groups in the study sites

Table 2 Entomological inoculation rate (EIR) in Anopheles gambiae s.l., Anopheles funestus group and Anopheles nili group in the Péhunco and Kérou districts

\begin{tabular}{|c|c|c|c|c|c|c|c|c|c|c|c|}
\hline & \multirow[t]{2}{*}{$\begin{array}{l}\text { Biting } \\
\text { locations }\end{array}$} & \multicolumn{2}{|c|}{$\begin{array}{l}\text { Number of collected } \\
\text { mosquitoes }\end{array}$} & \multicolumn{2}{|c|}{ HBR (b/h/night) } & \multicolumn{2}{|c|}{$\begin{array}{l}\text { Sporozoite index ( } \mathrm{N} \\
\text { tested) }\end{array}$} & \multicolumn{2}{|c|}{ EIR (ib/h/night) } & \multicolumn{2}{|c|}{ EIR (ib/h/month) } \\
\hline & & Kérou & Péhunco & Kérou & Péhunco & Kérou & Péhunco & Kérou & Péhunco & Kérou & Péhunco \\
\hline \multirow[t]{3}{*}{ An. gambiae s.l. } & Indoors & 430 & 74 & $26.875^{\mathrm{a}}$ & $4.625^{\mathrm{a}}$ & $0.025(121)^{\mathrm{a}}$ & $0.014(66)^{\mathrm{a}}$ & 0.672 & 0.065 & $20.156^{\mathrm{a}}$ & $1.943^{\mathrm{a}}$ \\
\hline & Outdoors & 408 & 54 & $25.5^{\mathrm{a}}$ & $3.375^{\mathrm{a}}$ & $0.008(120)^{\mathrm{a}}$ & $0(50)^{\mathrm{a}}$ & 0.204 & 0 & $6.120^{\mathrm{b}}$ & $0^{\mathrm{b}}$ \\
\hline & Total & 838 & 128 & $26.19^{*}$ & $4^{*}$ & $0.017^{*}(241)$ & $0.009(116)$ & 0.435 & 0.034 & $13.05^{*}$ & 1.02 \\
\hline \multirow[t]{3}{*}{ An. funestus group } & Indoors & 9 & 0 & $0.5625^{b}$ & $0^{\mathrm{a}}$ & $0.111(9)^{\mathrm{a}}$ & 0 & 0.062 & 0 & $1.873^{c}$ & 0 \\
\hline & Outdoors & 12 & 1 & $0.75^{b}$ & $0.0625^{\mathrm{a}}$ & $0(12)^{a}$ & $0(1)$ & 0 & 0 & $0^{d}$ & 0 \\
\hline & Total & 21 & 1 & $0.656^{\ddagger}$ & $0.031^{\ddagger}$ & $0.048(21)^{*}$ & $0(1)$ & 0.031 & 0 & $0.9375^{\ddagger}$ & 0 \\
\hline \multirow[t]{3}{*}{ An. nili group } & Indoors & 51 & 0 & $3.1875^{c}$ & 0 & $0.02(51)^{\mathrm{a}}$ & 0 & 0.064 & 0 & $1.913^{\mathrm{e}}$ & 0 \\
\hline & Outdoors & 109 & 0 & $6.8125^{d}$ & 0 & $0.009(109)^{\mathrm{a}}$ & 0 & 0.061 & 0 & $1.839^{\mathrm{e}}$ & 0 \\
\hline & Total & 160 & 0 & $5^{*}$ & 0 & $0.0125(160)^{*}$ & 0 & 0.063 & 0 & $1.875^{¥}$ & 0 \\
\hline
\end{tabular}

b/h, bite/human; ib/h, infected bite/human; N, number of mosquitoes

$a, b, c, d, e$ Values with different superscripts at the two biting locations of the same district are significantly different $(p<0.05)$

${ }^{*}, \neq, \neq *$ The total values with different superscripts in a same district are significantly different $(p<0.05)$

For the SI, no significant difference was recorded between the three vectors in the Kérou district ( $\mathrm{p}=0.496$ ). In Péhunco, only An. gambiae s.l. was found positive for P. falciparum antigen (Table 2).
In Kérou, the indoors EIR of An. gambiae s.l. (20.156 infected bites/human/month) and An. funestus group (1.873 infected bites/human/month) were significantly higher than that recorded outdoors [An. gambiae 
s.l.: 6.12 infected bites/human/month $(\mathrm{p}<0.0001)$; An. funestus group: 0 infected bites/human/month $(\mathrm{p}=0.0005)]$. In the same district, the indoor $(1.913$ infected bites/human/month) and the outdoor (1.839 infected bites/human/month) EIR of $A n$. nili group was similar $(\mathrm{p}=1)$. Furthermore, in the district of Kérou, the malaria transmission risk by An. gambiae s.l. (13.05 infected bites/human/month) was significantly higher than the malaria transmission risk of the An. nili group (1.875 infectious bites/human/month) $(\mathrm{p}=0.0009)$ and the An. funestus group (0.938 infected bites/human/ month) $(\mathrm{p}<0.0001)$. It should be noted that the EIR of $A n$. nili group was significantly higher than that of $A n$. funestus group in Kérou $(\mathrm{p}<0.0001)$ during the study period. In Péhunco, the indoor EIR for An. gambiae s.l. (1.943 infected bites/human/month) was significantly higher than that noted outdoor $(0$ infected bites per month) $(\mathrm{p}<0.0001)$ (Table 2).
Parity rate of An. gambiae s.l., An. funestus group and An. nili group

Figure 3 shows the different parity rates with $88 \%$ [78.9997.01], 57.14\% [35.97-78.31] and 46\% [32.19-59.81] for An. gambiae s.l., An. funestus group and $A n$. nili group in the Kérou district, respectively. The parity rate in $A n$. gambiae s.l. was significantly higher than that of $A n$. funestus group $(\mathrm{p}=0.004)$ and An. nili group $(\mathrm{p}<0.0001)$. In Pehunco, the parity rate recorded for $A n$. gambiae s.l. was $72 \%$ [59.55-84.45].

\section{Blood feeding rate and blood meal source in An. gambiae} s.l

The blood feeding rate of An. gambiae s.l. collected inside houses after PSC was 63.16\% in Péhunco against $60.53 \%$ in Kérou $(\mathrm{p}=0.847)$. In both districts, the majority of An. gambiae s.l. vectors took their blood meal on human (91.30\% in Kérou against $100 \%$ in Péhunco). In Kérou, $4.35 \%(1 / 23)$ of the collected An. gambiae s.l. blood fed on beef and, the same proportion on sheep (Table 3 ).

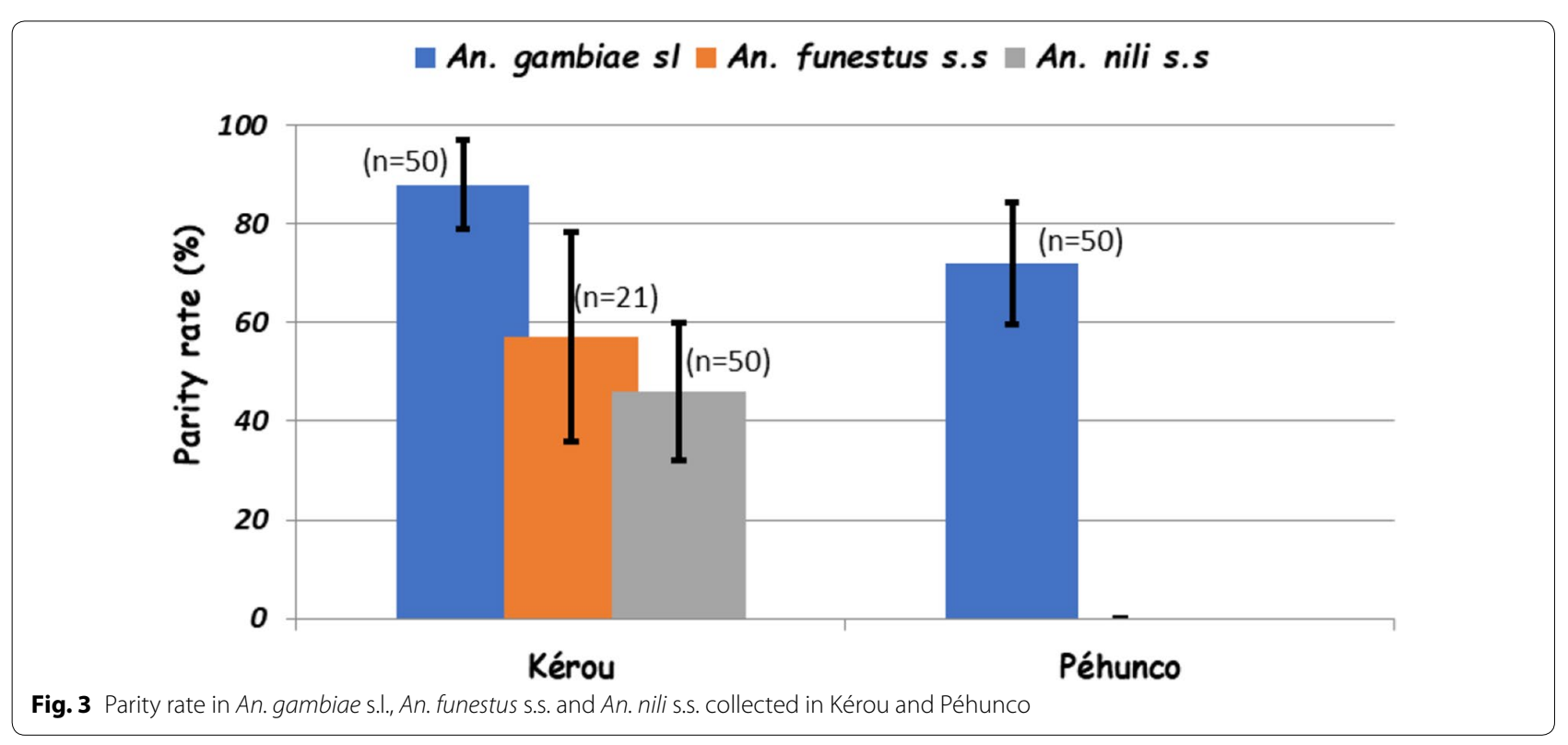

Table 3 Blood meal origin in Anopheles gambiae s.l. collected indoors in Kérou and Péhunco

\begin{tabular}{|c|c|c|c|c|c|c|c|}
\hline \multirow[t]{2}{*}{ Districts } & \multirow[t]{2}{*}{ T. collected } & \multirow{2}{*}{$\begin{array}{l}\text { T. } \\
\text { Blood fed }\end{array}$} & \multirow{2}{*}{$\begin{array}{l}\text { Blood } \\
\text { feeding rate } \\
(\%)\end{array}$} & \multicolumn{4}{|c|}{ Blood meal origin in An. gambiae s.l. } \\
\hline & & & & N. Human (\%) & $\begin{array}{l}\text { N. Beef } \\
(\%)\end{array}$ & $\begin{array}{l}\text { N. Sheep } \\
(\%)\end{array}$ & $\begin{array}{l}\text { N. Pig } \\
\text { (\%) }\end{array}$ \\
\hline Péhunco & 19 & 12 & 63.16 & $12(100)$ & & & 0 \\
\hline Kérou & 38 & 23 & 60.53 & $21(91.30)$ & $1(4.35)$ & $1(4.35)$ & 0 \\
\hline Total & 57 & 35 & 61.40 & $22(62.86)$ & $1(2.86)$ & $1(2.86)$ & 0 \\
\hline
\end{tabular}

T, total of mosquitoes; N., number of mosquitoes having taken their blood meal on 
L1014F $k d r$ and G1 19S ace-1 allele frequencies in An. gambiae and An. coluzzii

The L1014F $k d r$ mutation was found at very high frequencies in both Péhunco (86\% and 100\% respectively in An. gambiae and An. coluzzii) and Kérou (83\% and 73\% respectively in An. gambiae and An. coluzzii) (Table 4). In each district, the allelic frequencies of the L1014F $k d r$ mutation were similar in An. gambiae and An. coluzzii $(\mathrm{p}>0.05)$.

The G119S ace-1 mutation was also recorded in the two districts but at low levels with allelic frequencies of 5\% and 0\%, respectively, in An. gambiae and An. coluzzii in Péhunco and, 7.3\% and 5\%, respectively, in An. gambiae and An. coluzzii in Kérou (Table 4). No significant difference was also recorded between the allelic frequencies of the G119S ace-1 mutation of An. coluzzii and An. gambiae in both districts $(\mathrm{p}>0.05)$.

\section{Discussion}

The study of malaria vectors in an area is a prerequisite not only to understand the epidemiology of the disease but also to implement a strategy for effective and targeted control of those vectors. In the current study, 12 mosquito species including 6 anophelinae were identified in the two surveyed districts. Among these 6 Anopheles species, two (An. gambiae s.l. and An. funestus group) have already been implicated in malaria transmission in Benin $[13,17,18]$. During this cross-sectional study, they were found in both study districts but, An. nili group was found only in Kérou. The three vector species ( $A n$. gambiae s.l., An. funestus group and An. nili group) identified in Kérou live in sympatry in this savannah zone. This finding is similar to those of several authors in West Africa [30, 31].

In Péhunco and Kérou, An. gambiae and An. coluzzii are the only members of the An. gambiae complex recorded with a predominance of An. gambiae (96.43\% and 78.43\%, respectively, in Péhunco and Kérou). No species of An. arabiensis was identified after PCR in both districts. This could be due to anthropogenic actions such as deforestation and urbanization that destroy its natural habitats causing its gradual disappearance in some areas of northern Benin as reported by Aïkpon et al. [32] and Salako et al. [33]. All the specimens of the $A n$. nili and An. funestus groups identified by PCR were An. nili s.s. and An. funestus s.s. in the district of Kérou. These results corroborate those of Djouaka et al. [19, 34] who found An. funestus s.s. as the only species of the An. funestus group in the areas of Pahou and Kpomè in southern Benin. The results are also similar to works by Carnevale et al. [35], Dia et al. [36] and Adja et al. [31], who found An. nili s.s. as the only species in forest zone respectively in Cameroon, Senegal and Côte d'Ivoire.

The number of An. funestus group collected in both districts was low during the study period as was also reported by some authors in the area and around [32, 37, 38]. This could be justified by the scarcity of breeding sites favorable to the development of this species. Moreover, contrary to An. gambiae s.l., An. nili group was found to be exophagic (significantly higher biting activity outdoors compared to indoors) in Kérou. This low biting behaviour of An. nili group inside the dwellings had also been reported in Nigeria [39]. Kérou being a savanna area, this behaviour of An. nili group confirms the results of other authors who have shown that savanna populations of An. nili group are more exophagic and exophilic [40, 41].

In Kérou, each inhabitant receives 5 bites of An. nili group per night. This biting rate was significantly higher than the one of An. funestus group and not negligible for just four nights of collection. This reflects the presence of breeding sites favorable to the development of this species in the area. In fact, Kérou is close to several rivers, and the water level of these rivers is kept high for a good part of the year by the rain. This flow of water contributes to the development of several permanent mosquito breeding sites. This could probably explain the high density of the populations of the An. nili group in Kérou. As a result, in an area with multiple vectors, variation in ecological, spatial and temporal parameters directly influences the relative role of each species in malaria transmission [42]. The biting rate of An. gambiae s.l. was very high in Kérou (26.19 bites/human/night) and in Péhunco (4 bites/human/night) compared to the other

Table 4 Allelic frequencies of L1014F kdr and G119S ace-1 mutations in Anopheles gambiae and Anopheles coluzzii in the Péhunco and Kérou districts

\begin{tabular}{|c|c|c|c|c|c|c|c|c|c|c|c|c|}
\hline & \multirow[t]{2}{*}{ Species } & \multirow[t]{2}{*}{$\mathrm{N}$ tested } & \multicolumn{4}{|c|}{ L1014F Kdr } & \multirow[t]{2}{*}{$p$ value } & \multicolumn{4}{|c|}{ G119S Ace-1 } & \multirow[t]{2}{*}{$p$-value } \\
\hline & & & RR & RS & SS & $\mathrm{F}(\mathrm{L} 1014 \mathrm{~F} K d r)$ & & RR & RS & SS & F(G119S Ace-1) & \\
\hline \multirow[t]{2}{*}{ Péhunco } & An. gambiae & 54 & 42 & 9 & 3 & 0.86 & \multirow[t]{2}{*}{0.957} & 0 & 5 & 49 & 0.05 & \multirow[t]{2}{*}{1} \\
\hline & An. coluzzii & 2 & 2 & 0 & 0 & 1 & & 0 & 0 & 2 & 0 & \\
\hline \multirow[t]{2}{*}{ Kérou } & An.gambiae & 41 & 30 & 8 & 3 & 0.83 & \multirow[t]{2}{*}{0.439} & 0 & 6 & 35 & 0.073 & \multirow[t]{2}{*}{1} \\
\hline & An. coluzzii & 11 & 7 & 2 & 2 & 0.73 & & 0 & 1 & 10 & 0.05 & \\
\hline
\end{tabular}


species and allows this vector to maintain the transmission of malaria in both districts.

Another important aspect of the current study is the involvement of An. nili group in malaria transmission in Benin. Indeed, the SI of An. nili group was $1.25 \%$ in Kérou. This index is similar to that recorded by Carnevale et al. [35] in Cameroon and lower than the one of Elissa et al. [43] in Gabon and Adja et al. [31] in Côte d'Ivoire. The sporozoite indexes of An. gambiae s.l. in Kérou (1.7\%) and Péhunco $(0.9 \%)$ were lower than those reported by previous studies in different areas of Benin [16, 33, 37]. This could be due to the low number of tested mosquitoes in the short collection period covered by the current study as compared to previous records which considered a longer time period.

This study also showed malaria transmission by different mosquito species in the Kérou district. An. gambiae s.l. and An. nili group share in the indoors and outdoors malaria transmission. In An. funestus group where EIR has been observed indoors, no definitive conclusion can be drawn as to its participation in outdoor transmission since the collection period in this study is short. As previously found in several sites in Benin [13-18], An. gambiae s.l. also remains the primary vector of malaria transmission in Kérou (13.05 infected bites/human/ month), followed by An. nili group (1.87 infected bites/ human/month) and An. funestus group (0.94 bites/ human/month).

The EIR by An. gambiae s.l. in Kérou was higher than those reported in a longitudinal study by Salako et al. [37] in similar bioecological areas (Kandi and Gogounou) in the department of Alibori, Benin. In Péhunco, each inhabitant receives 1.02 infected bites of An. gambiae s.l. per month. The high transmission by An. gambiae s.l. in Kérou compared to both An. funestus group and An. nili group may be due to its significantly higher physiological age compared to the one of the other mosquito species $(\mathrm{p}<0.05)$. The small number of An. funestus group collected in each district could explain its low level of malaria transmission. Findings of this study shows that no specimen of An. nili group and An. funestus group was collected indoors after PSC. This could be due to the low sampling of mosquitoes performed during our survey. An. gambiae s.l. which was the most frequent vector in the two districts takes mostly its blood meal on humans, thus confirming its anthropophagic nature [33].

Regarding the presence of resistance mechanisms in An. gambiae s.l., the L1014F $K d r$ mutation was found at very high frequencies in its two detected sibling species (An. gambiae and An. coluzzii) in the two districts. Contrary to the works of Gnanguenon et al. [44], Yahouédo et al. [45] and Akogbeto et al. [33] in some locations of southern and northern Benin, no significant difference was noted between the allelic frequencies of the L1014F $k d r$ mutation of An. gambiae and An. coluzzii in Kérou and Péhunco. This result corroborates those of Salako et al. [46] who also found no significant difference between the L1014F $k d r$ frequencies of An. gambiae and An. coluzzii in Djougou, Ségbana and Copargo, northern Benin. The trend was the same for the relatively low allelic frequencies of the G119S ace-1 mutation of An. gambiae and An. coluzzii of the two study districts. However, the highest allelic frequencies of the G119S Ace-1 mutation was recorded in An. gambiae in each zone with values ranging from 5 to $7.3 \%$. In An. coluzzii, this frequency varied from $0 \%$ in Péhunco to $5 \%$ in Kérou.

\section{Conclusion}

In the present study, An. gambiae s.l., An. funestus group and $A n$. nili group were the three most important vectors that transmit malaria in the Kérou district. This is the first report on the contribution of the $A n$. nili group as a secondary vector of malaria transmission in Benin. This suggests broader studies involving other districts to determine if other Anopheles species also contribute to malaria transmission. This will help a better orientation of vector control interventions.

\section{Abbreviations \\ HLC: human landing catches; HBR: human biting rate; PSC: pyrethrum spray catches; ELISA : enzyme-linked immunosorbent assay; PCR : polymerase chain reaction; $S I$ : sporozoite index; EIR : entomological inoculation rate; CSP : circumsporozoite protein.}

\section{Authors' contributions}

RAO, FT, GGP, RA and MCA designed the study. RAO, AF and CK performed the fields activities. RAO, AS and WS carried out the laboratory's activities. RAO drafted the manuscript and analysed the data. MCA, MA, GGP, ADS, BA and RA critically revised the manuscript for intellectual content. All authors read and approved the final manuscript

\section{Author details \\ ${ }^{1}$ Ecole de Gestion et d'Exploitation des Systèmes d'Elevage, Université Nationale d'Agriculture, Kétou, Benin. ${ }^{2}$ Centre de Recherche Entomologique de Cotonou (CREC), 06 BP 2604 Cotonou, Benin. ${ }^{3}$ National Malaria Control Programme, Ministry of Health, Cotonou, Benin. ${ }^{4}$ Faculté des Sciences et Tech- niques, Université d'Abomey-Calavi, Abomey-Calavi, Benin. ${ }^{5}$ Ecole Normale Supérieure de Natitingou, Université Nationale des Sciences, Technologies, Ingénierie et Mathématiques, Natitingou, Benin. ${ }^{6}$ Faculté d'Agronomie, Uni- versité de Parakou, Parakou, Benin. ${ }^{7}$ Conseil National de Lutte contre le SIDA la Tuberculose, le Paludisme, les Hépatites et les épidémies, Cotonou, Benin.}

\section{Acknowledgements}

We are grateful to the Centre de Recherche Entomologique de Cotonou (CREC) which supported financially this study. We thank the team of CREC for their technical assistance during field work and laboratory. We also thank the people of Kérou and Péhunco for their collaboration.

Competing interests

The authors declare that they have no competing interests. 


\section{Availability of data and materials}

The data supporting the conclusions of this article are included within the article. The raw data used in this study are available from the corresponding author upon reasonable request.

\section{Consent for publication}

Not applicable.

\section{Ethics approval and consent to participate}

This study was received the ethical approval by the Institutional Ethics Committee of CREC (IECC). The mosquito collectors gave their consent before participate to this study. They were checked up by treatment malaria after mosquito collection and were vaccinated against yellow fever.

\section{Funding}

This work has been financially supported by Centre de Recherche Entomologique de Cotonou (CREC).

\section{Publisher's Note}

Springer Nature remains neutral with regard to jurisdictional claims in published maps and institutional affiliations.

Received: 4 February 2019 Accepted: 23 April 2019

Published online: 29 April 2019

\section{References}

1. Calzolari M. Mosquito-borne diseases in Europe: an emerging public health threat. Reports Parasitol. 2016;5:1-12.

2. WHO. World Malaria report 2017. Geneva: World Health Organization; 2017.

3. Rogier MPC, Parzi MCD, Spiegel MAC. Histoire naturelle et épidémiologie du paludisme. In: Saissy JM, editor. Paludisme grave. Paris: Arnette; 2001.

4. Kazembe LN, Kleinschmidt I, HoltzTH. Spatial analysis and mapping of malaria risk in Malawi using point-referenced prevalence of infection data. Int J Health Geograph. 2006;5:41.

5. Antonio-Nkondjio C, Awono-Ambene P, Toto JC, Meunier JY, ZebazeKemleu S, Nyambam R, et al. High malaria transmission intensity in a village close to Yaounde, the capital city of Cameroon. J Med Entomol. 2002;39:350-5.

6. White NJ. Plasmodium knowlesi: the fifth human malaria parasite. Clin Infect Dis. 2008;46:172-3.

7. Carnevale P, Robert V. Les anophèles, biologie, transmission du paludisme et lutte antivectorielle. IRD Editions. 2009.

8. Fontenille D, Simard F. Unravelling complexities in human malaria transmission dynamics in Africa through a comprehensive knowledge of vector populations. Comp Immun Microbiol Infect Dis. 2004;27:357-75.

9. Becker N, Petric D, Zgomba M, Boase C, Madon M, Dahl C, et al. Mosquitoes and their Control. 2nd ed. Berlin: Springer; 2010.

10. Hamon J, Mouchet J. Les vecteurs secondaires du paludisme humain en Afrique. Méd Trop. 1961;21:643-60.

11. Awono-Ambene HP, Kengne P, Simard F, Antonio-Nkondjio C, Fontenille D. Description and bionomics of Anopheles (Cellia) ovengensis (Diptera: Culicidae), a new malaria vector species of the Anopheles nili group from south Cameroon. J Med Entomol. 2004;41:561-8.

12. Akogbéto M. Lagoonal and coastal malaria at Cotonou: entomological findings. Santé. 2000;10:267-75.

13. Djènontin A, Bio-Bangana S, Moiroux N, Henry M-C, Bousari O, Chabi J, et al. Culicidae diversity, malaria transmission and insecticide resistance alleles in malaria vectors in Ouidah-Kpomasse-Tori district from Benin (West Africa): a pre-intervention study. Parasit Vectors. 2010;3:83.

14. Padonou GG, Sezonlin M, Gbedjissi GL, Ayi I, Azondekon R, Djènontin A, et al. Biology of Anopheles gambiae and insecticide resistance: entomological study for a large scale of indoor residual spraying in South East Benin. J Parasitol Vector Biol. 2011;3:59-68.

15. Ossè RA, Aïkpon R, Gbédjissi GL, Gnanguenon V, Sèzonlin M, Govoétchan $R$, et al. A shift from indoor residual spraying (IRS) with bendiocarb to Long-Lasting Insecticidal (mosquito) Nets (LLINs) associated with changes in malaria transmission indicators in pyrethroid resistance areas in Benin. Parasit Vectors. 2013;6:73.

16. Sovi A, Govoétchan R, Tokponnon F, Hounkonnou H, Aïkpon R, Agossa F, et al. Impact of land-use on malaria transmission in the plateau region, southeastern Benin. Parasit Vectors. 2013;6:352.

17. Aïkpon R, Sèzonlin M, Tokponon F, Okè M, Oussou O, Oké-Agbo F, et al. Good performances but short lasting efficacy of Actellic 50 EC Indoor Residual Spraying (IRS) on malaria transmission in Benin. West Africa. Parasit Vectors. 2014;7:256.

18. Gnanguenon V, Govoetchan R, Agossa FR, Ossè R, Oke-Agbo F, Azondekon $\mathrm{R}$, et al. Transmission patterns of Plasmodium falciparum by Anopheles gambiae in Benin. Malar J. 2014;13:444.

19. Djouaka R, Riveron JM, Yessoufou A, Tchigossou G, Akoton R, Irving H, et al. Multiple insecticide resistance in an infected population of the malaria vector Anopheles funestus in Benin. Parasit Vectors. 2016;9:453.

20. Afrique Conseil. Monographie de la commune de Kérou et de Péhunco. 2006.

21. Gillies MT, Coetzee M. A Supplement to the Anophelinae of Africa South of the Sahara (Afrotropical Region). Publ South Afr Inst Med Res. 1987; 1987:55.

22. Detinova TS, Gillies MT. Observations on the determination of the Age composition and epidemiological importance of populations of Anopheles gambiae Giles and Anopheles funestus Giles in Tanganyika. Bull World Health Organ. 1964;30:23-8.

23. Wirtz R, Zavala F, Charoenvit Y, Campbell G, Burkot T, Schneider I, et al. Comparative testing of monoclonal antibodies against Plasmodium falciparum sporozoites for ELISA development. Bull World Health Organ. 1987;65:39.

24. Santolamazza F, Mancini E, Simard F, Qi Y, Tu Z, Torre A. Insertion polymorphisms of SINE200 retrotranposons within speciation island of Anopheles gambiae molecular forms. Malar J. 2008;7:163.

25. Koekemoer LL, Kamau L, Hunt RH, Coetzee M. A cocktail polymerase chain reaction assay to identify members of the Anopheles funestus (Diptera: Culicidae) group. Am J Trop Med Hyg. 2002;66:804-11.

26. Kengne P, Awono-Ambene P, Nkondjio CA, Simard F, Fontenille D. Molecular identification of the Anopheles nili group of African malaria vectors. Med Vet Entomol. 2003;17:67-74.

27. Martinez-Torres D, Chandre F, Williamson MS, Darriet F, Berge JB, Devonshire AL, et al. Molecular characterization of pyrethroids knockdown resistance $(\mathrm{kdr})$ in the major malaria vector Anopheles gambiae s.s. Insect Mol Biol. 1998;7:179-84

28. Weill M, Malcolm C, Chandre F, Mogensen K, Berthomieu A, Marquine M. The unique mutation in ace-1 giving high insecticide resistance is easily detectable in mosquito vectors. Insect Mol Biol. 2004;13:1-7.

29. Beier JC, Perkins PV, Wirtz RA, Koros J, Diggs D, Gargam TPII, et al. Bloodmeal identification by direct enzyme-linked immunosorbent assay (ELISA) tested on Anopheles (Diptera: Culicidae) in Kenya. J Med Entomol. 1988;25:9-16.

30. Fofana D, Koné AB, Konan YL, Konan KL, Doannio JMC, N'Goran KE. Diversité spécifique et nuisance culicidienne dans les villages de N'gatty et d'Allaba en milieu côtier lagunaire de Côte-d'Ivoire. Cahiers Santé. 2010;20:73-9.

31. Adja AM, N'Goran EK, Koudou BG, Dia I, Kengne P, Fontenille D, et al. Contribution of Anopheles funestus, An. gambiae and An. nili (Diptera: Culicidae) to the perennial malaria transmission in the southern and western forest areas of Côte d'Ivoire. Ann Trop Med Parasitol. 2011;105:13-24.

32. Aïkpon R, Osse R, Govoetchan R, Sovi A, Oke-Agbo F, Akogbeto MC. Entomological baseline data on malaria transmission and susceptibility of Anopheles gambiae to insecticides in preparation for indoor residual spraying (IRS) in Atacora, (Benin). J Parasitol Vector Biol. 2013;5:102-11.

33. Akogbéto MC, Salako AS, Dagnon F, Aïkpon R, Kouletio M, Sovi A, et al. Blood feeding behaviour comparison and contribution of Anopheles coluzzii and Anopheles gambiae, two sibling species living in sympatry, to malaria transmission in Alibori and Donga region, northern Benin, West Africa. Malar J. 2018;17:307.

34. Djouaka $\mathrm{R}$, Irving $\mathrm{H}$, Tukur Z. Exploring mechanisms of multiple insecticide resistance in a population of the malaria vector Anopheles funestus in Benin. PLoS ONE. 2011;6:e27760.

35. Carnevale P, Le Goff G, Toto JC, Robert V. Anopheles nili as the main vector of human malaria in villages of southern Cameroon. Med Vet Entomol. 1992:6:135-8. 
36. Dia I, Diop T, Rakotoarivony L, Kengne P, Fontenille D. Bionomics of Anopheles gambiae Giles, An. arabiensis Patton, An. funestus Giles and An. nili (Theobald) (Diptera: Culicidae) and transmission of Plasmodium falciparum in a Sudano-Guinean zone (Ngari, Senegal). J Med Entomol. 2003;40:279-83

37. Salako AS, Ahogni I, Kpanou C, Sovi A, Azondekon R, Sominahouin AA, et al. Baseline entomologic data on malaria transmission in prelude to an indoor residual spraying intervention in the regions of Alibori and Donga, Northern Benin, West Africa. Malar J. 2018;17:392.

38. Aïkpon R, Ossè R, Ahogni I, Dagnon F, Tokponon F, Lyikirenga L, et al. Residual malaria transmission assessment: quantification of the relative risk of malaria transmission at different night-time and location in Atacora region in Benin, West Africa. J Entomol Zool Studies. 2018;6:1026-32.

39. Oyewole IO, Ibidapo CA, Okwa OO, Oduola AO, Adeoye GO, Okoh HI, et al. Species composition and role of Anopheles mosquitoes in malaria transmission along Badagry axis of Lagos Lagoon, Lagos, Nigeria. Int J Insect Sci. 2010;2:51-7.

40. Awono-Ambene P, Antonio-Nkondjio C, Toto J, Ndo C, Etang J, Fontenille D, et al. Epidemological importance of the Anopheles nili group of malaria vectors in equatorial villages of Cameroon, Central Africa. Sci Med Afr. 2009;1:13-20.

41. Antonio-Nkondjio C, Kerah C, Simard F, Awono-Ambene H, Mouhamadou C, Tchuinkam T, et al. Complexity of malaria vectorial system in
Cameroon: contribution of secondary vectors to malaria transmission. J Med Entomol. 2006;43:1215-21.

42. Bigoga JD, Manga L, Titanji VP, Coetzee M, Leke RG. Malaria vectors and transmission dynamics in coastal south-western Cameroon. Malar J. 2007;6:5.

43. Elissa N, Karch IS, Bureau PH, Ollomo B, Lawoko IM, Yangari IP, et al. Malaria transmission in a region of savanna-forest mosaic, Haut-Ogooué, Gabon. J Am Mosq Control Assoc. 1999;15:15-23.

44. Gnanguenon V, Agossa FR, Badirou K, Govoetchan R, Anagonou R, OkeAgbo F, et al. Malaria vectors resistance to insecticides in Benin: current trends and mechanisms involved. Parasit Vectors. 2015;8:223

45. Yahouédo GA, Cornelie S, Djégbé I, Ahlonsou J, Aboubakar S, Soares C, et al. Dynamics of pyrethroid resistance in malaria vectors in southern Benin following a large-scale implementation of vector control interventions. Parasit Vectors. 2016;9:385.

46. Salako AS, Ahogni I, Aïkpon R, Sidick A, Dagnon F, Sovi A, et al. Insecticide resistance status, frequency of L1014F Kdr and G119S Ace-1 mutations, and expression of detoxification enzymes in Anopheles gambiae (s.l.) in two regions of northern Benin in preparation for indoor residual spraying. Parasit Vectors. 2018;11:618
Ready to submit your research? Choose BMC and benefit from:

- fast, convenient online submission

- thorough peer review by experienced researchers in your field

- rapid publication on acceptance

- support for research data, including large and complex data types

- gold Open Access which fosters wider collaboration and increased citations

- maximum visibility for your research: over 100M website views per year

At BMC, research is always in progress.

Learn more biomedcentral.com/submissions 